\title{
STATUS YURIDIS BURSA EFEK SEBAGAI PENGATUR KEGIATAN PERDAGANGAN PASAR MODAL
}

\author{
Gilbert Josua Tulus Hartarto \\ Program Studi Magister Kenotariatan Fakultas Hukum Universitas Airlangga \\ Jl. Dharmawangsa Dalam Selatan, Kota Surabaya, 60286 \\ gilbertjosua1996@gmail.com
}

\begin{abstract}
Stock Exchange has a role as regulator of securities trading in the capital market. In this case, the author raises legal issues concerning the role and juridical status of the stock exchange as a regulator of securities trading activities. Thus, this article is written in order to provide scientific insight, especially in the field of capital market law with regard to the said issues. By using the method of normative research with comprehensive literature review, this article is expected to produce a conclusion that the stock exchange has clear legal status and role as a regulator of securities trading activities in the capital market. Considering that the juridical status of the stock exchange has not been firmly stated under laws and regulations, the author argued that there shall be a law which regulates the stock exchange to confirm the legal status of the stock exchange.
\end{abstract}

Keywords: Stock Exchange; Regulator; Capital Market.

\begin{abstract}
Abstrak
Bursa Efek memiliki peran sebagai regulator perdagangan efek dalam pasar modal. Dalam hal ini, penulis mengangkat isu hukum yakni peran Bursa Efek dan status yuridis Bursa Efek sebagai regulator kegiatan perdagangan efek. Tujuan penulisan artikel ini adalah mengulas peran lembaga Bursa Efek dan status yuridis lembaga Bursa Efek. Penulis mengangkat isu hukum tersebut dikarenakan status yuridis Bursa Efek belum dinyatakan secara tegas kedudukannya sehingga dalam penulisan ini. Metode yang digunakan dalam penulisan ini adalah penelitian normatif dengan tinjauan kepustakaan. Penulis memiliki gagasan bahwa Bursa Efek perlu dibuatkan suatu Undang-Undang yang mengatur Bursa Efek guna mempertegas status kedudukan Bursa Efek secara yuridis. Penulisan ini menghasilkan kesimpulan bahwa Bursa Efek memiliki kejelasan status yuridis dalam perannya sebagai regulator kegiatan perdagangan efek di pasar modal.
\end{abstract}

Kata Kunci: Bursa Efek; Regulator; Pasar Modal.

\section{A. Pendahuluan}

Bursa Efek merupakan salah satu badan hukum yang memiliki tugas utama yakni sebagai sarana untuk melaksanakan dan mengatur kegiatan perdagangan efek di pasar modal. Bursa Efek memiliki peran yang sangat penting sejak dahulu apabila ditelusuri dari sisi sejarahnya telah ada sejak jaman penjajahan Belanda, yakni dalam rangka menghimpun modal dari masyarakat atau disebut investor dengan dilakukan oleh para anggota bursa. Apabila ditinjau dari segi pandang ekonomi mikro yakni bagi para anggota bursa atau disebut emiten, Bursa Efek ditujukan untuk memperoleh modal segar yang dapat dipergunakan dalam rangka melakukan ekspansi usaha dan sebagainya. Sedangkan apabila ditinjau dari segi pandang ekonomi makro, Bursa Efek 
berperan penting dalam upaya menggerakkan roda perekonomian negara sehingga apabila kegiatan perdagangan efek dalam pasar modal yang dilaksanakan di Bursa Efek menghasilkan gambaran kondisi perdagangan yang positif, maka hal tersebut dapat berakibat tercapainya kinerja positif perekonomian negara, demikian pula sebaliknya.

Kegiatan Bursa Efek di Indonesia pada jaman penjajahan Belanda dahulu dilaksanakan di kota Batavia, Semarang dan Surabaya sempat berhenti pada saat jaman penjajahan Jepang dan kemudian berlanjut hingga masa perang kemerdekaan Indonesia. Pada jaman Orde Lama, kegiatan Bursa Efek sempat diaktifkan kembali namun tidak lama kemudian kembali berhenti dikarenakan kondisi perekonomian pada akhir Orde Lama yang berkinerja buruk. Hingga pada akhirnya pada tanggal 10 Agustus 1977, Bursa Efek diresmikan pembukaannya kembali oleh Presiden Soeharto berdasarkan Keputusan Presiden Nomor 52 Tahun 1976 tentang Pasar Modal.

Bursa Efek yang merupakan badan hukum berbentuk perseroan ternyata memiliki keunikan tersendiri yang membedakan bursa efek ini dengan perusahaan perseroan lainnya dimana dalam hal ini akan dibahas lebih lanjut pada bagian pembahasan. Salah satu karakteristik unik Bursa Efek salah satunya bahwa sebagai perseroan yang bersifat nirlaba, Bursa Efek tidak membagikan dividen kepada para pemegang sahamnya (Rahmah, 2019). Berikutnya, gambaran pembahasan yang akan diulas pada bab pembahasan artikel ini adalah meneliti serta membahas isu hukum yang diangkat oleh Penulis, yakni peran Bursa Efek dan status yuridis Bursa Efek sebagai regulator kegiatan perdagangan efek di pasar modal dimana dalam Bursa Efek terdapat para anggota bursa yang juga merupakan perusahaan-perusahaan yang terlibat dalam kegiatan perdagangan efek.

Urgensi penulisan ini adalah tidak hanya sebagai upaya untuk menambah sumbangsih keilmuan dalam bidang hukum yang terkait dengan pasar modal, namun juga untuk menghasilkan suatu kesimpulan berupa gagasan bahwa Bursa Efek perlu dipertegas status badan hukumnya. Orisinalitas penulisan ini dengan penulisanpenulisan yang lainnya seperti "Karakteristik Bursa Efek Sebagai Self Regulatory Organization dan Eksistensi PT. Bursa Efek Indonesia Sebagai Lembaga Penyelenggara Perdagangan Efek di Indonesia" adalah pada tulisan tersebut terdapat pembahasan mengenai konflik kepentingan, sedangkan dalam penulisan ini tidak ada pembahasan secara khusus tentang hal tersebut. Sementara itu, pada disertasi yang berjudul "Eksistensi PT Bursa Efek Indonesia Sebagai Lembaga Penyelenggara Perdagangan Efek di Indonesia" terdapat kesimpulan yang menyatakan bahwa rencana demutualisasi bursa bertentangan dengan dasar kebangsaan sedangkan dalam penulisan ini tidak ada pembahasan secara khusus terkait hal tersebut.

Peran dan Karakteristik Bursa Efek diangkat karena Penulis akan mengulas mengenai peran bursa efek sebagai pelaksana dan pengatur kegiatan perdagangan efek di pasar modal serta membahas mengenai karakteristik Bursa Efek sebagai perseroan yang memiliki keunikan tersendiri dalam hal cara kinerjanya dibandingkan dengan perseroanperseroan yang lain. Sedangkan status yuridis Bursa Efek diangkat karena Penulis ingin mengulas mengenai status badan hukum apakah yang tepat untuk Bursa Efek apakah tetap berbentuk perseroan atau ditentukan sebagai bentuk badan hukum tersendiri.

Sehingga berdasarkan pemaparan yang telah dipaparkan sebelumnya, maka rumusan masalah yang akan Penulis angkat dalam penulisan ini adalah: Pertama, bagaimanakah peran dan karakteristik Bursa Efek? Kedua, bagaimanakah status yuridis Bursa Efek? Kedua permasalahan ini akan dibahas dalam pembahasan tulisan ini. 


\section{B. Pembahasan}

\section{Peran dan Karakteristik Bursa Efek}

Bursa Efek memiliki karakteristik unik yang tidak dimiliki oleh perseroan pada umumnya yaitu Bursa Efek sebagai perseroan yang bersifat nirlaba dengan tidak membagikan dividen kepada para pemegang sahamnya (Rahmah, 2019). Dari pernyataan tersebut diketahui bahwa Bursa Efek merupakan suatu badan hukum berbentuk perseroan yang bekerja tidak dalam rangka membagi keuntungan sehingga Bursa Efek adalah salah satu contoh bentuk perseroan yang berbeda dengan perseroan pada umumnya yang bekerja dengan tujuan mencari dan membagi keuntungan dalam rangka mewujudkan ekspansi usaha, pembiayaan kegiatan operasional, investasi atau penanaman aset dan sebagainya. Bursa Efek bekerja mencari keuntungan dimana dari keuntungan yang didapat ditujukan untuk pengembangan kegiatan perdagangan efek dalam pasar modal. Dari penyataan tersebut secara tidak langsung memberikan keterangan yang bersifat tersirat bahwa posisi kedudukan yuridis Bursa Efek itu sendiri seolah berada di antara kedudukan status sebagai perseroan dan yayasan. Hal tersebut memang demikian dikarenakan status sebagai perseroan yang ditujukan kepada Bursa Efek, namun Bursa Efek bersifat nirlaba seperti yayasan yang bekerja tidak untuk mencari keuntungan. Lebih jelasnya, Bursa Efek bersifat nirlaba tetapi bekerja mencari dan membagi keuntungan, namun bukan untuk kepentingan komersial, melainkan untuk kepentingan kegiatan perdagangan efek di pasar modal (Paulina, 2018).

Keunikan berikutnya dari Bursa Efek adalah Bursa Efek dianggap sebagai perseroan yang berisi kumpulan dari para perantara pedagang efek yang menjadi anggotanya (Club of Brokers), sehingga dalam Bursa Efek terdapat istilah anggota bursa (Rahmah, 2019). Hal ini membuktikan bahwa bursa efek memiliki karakteristik yang sangat berbeda dengan karakteristik perseroan pada umumnya dimana perseroan sebagaimana yang telah dinyatakan definisinya mengenai perseroan terbatas dalam Pasal 1 Angka 1 Undang-Undang Nomor 40 Tahun 2007 tentang Perseroan Terbatas bahwa perseroan adalah badan hukum yang merupakan persekutuan modal, yang didirikan berdasarkan perjanjian, melakukan kegiatan usaha dengan modal dasar yang seluruhnya terbagi dalam saham dan memenuhi persyaratan yang ditetapkan dalam Undang-Undang ini serta peraturan pelaksanaannya (Permatasari, 2018).

Menurut Pasal 1 Angka 2 UndangUndang Nomor 8 Tahun 1995 tentang Pasar Modal, anggota Bursa Efek adalah para perantara pedagang efek yang telah memperoleh izin usaha dari Otoritas Jasa Keuangan dimana dahulu kewenangan ini berada pada lembaga Bapepam (Badan Pengawas Pasar Modal) dan mempunyai hak untuk menggunakan sistem dan/atau sarana Bursa Efek sesuai dengan peraturan yang ada di Bursa Efek. Adapun menurut Angka 1 Peraturan III.A Lampiran Keputusan Direksi Bursa Efek Indonesia Nomor Kep00184/BEI/12-2018 tentang Keanggotaan Bursa (selanjutnya disebut Peraturan BEI III.A) jo. Angka 1.1 Peraturan Nomor III.I Lampiran Keputusan Direksi Bursa Efek Indonesia Nomor Kep-00022/BEI/02-2017 tentang Keanggotaan Margin dan Short Selling menyatakan hal yang serupa, yakni anggota Bursa Efek adalah para perusahaan efek yang telah memperoleh izin usaha dari Otoritas Jasa Keuangan sebagai perantara pedagang efek sebagaimana dimaksud dalam Pasal 1 angka 2 Undang-Undang Nomor 8 Tahun 1995 tentang Pasar Modal dan telah memperoleh persetujuan keanggotaan bursa untuk mempergunakan sistem dan/atau sarana bursa dalam rangka melakukan kegiatan perdagangan efek di bursa sesuai dengan peraturan bursa.

Selain itu, karakteristik unik yang hanya dimiliki dari Bursa Efek adalah dapat bertindak sebagai anggota bursa juga sekaligus berposisi sebagai pemegang saham (Rahmah, 2019). Hal ini tentunya mengingatkan pada konsep One Man Company yang dinyatakan dalam Omnibus 
Law Undang-Undang Cipta Lapangan Kerja yang menyatakan bahwa seseorang (satu orang) dapat mendirikan satu perseroan seorang diri sehingga hal tersebut menimbulkan konsekuensi hukum bahwa seseorang tersebut akan memiliki peran ganda, yakni sebagai pemegang saham perseroan yang dia dirikan serta dapat berposisi sebagai organ perseroan (Putri, 2020). Ketentuan mengenai pihak yang menjadi pemegang saham di bursa diatur dalam Pasal 8 Undang-Undang Pasar Modal, bahwa yang menjadi pemegang saham Bursa Efek adalah perusahaan efek yang telah memperoleh izin usaha sebagai perantara pedagang efek. Untuk menjadi anggota bursa di Bursa Efek, perusahaan pedagang efek tersebut harus memiliki saham di bursa efek karena berdasarkan ketentuan II.2 Peraturan BEI III.A menyatakan bahwa salah satu syarat untuk menjadi anggota bursa adalah perantara pedagang efek tersebut harus memiliki saham di Bursa Efek (Rahmah, 2019). Dengan demikian, sebagaimana yang dinyatakan dalam Pasal 6 dan Pasal 8 Undang-Undang Pasar Modal, Penulis memberikan hasil analisis sementara bahwa Bursa Efek adalah Perseroan yang diberi kewenangan oleh Undang-Undang Pasar Modal untuk menyelenggarakan kegiatan perdagangan efek di pasar modal serta mengawasi kinerja para anggota bursa yang merupakan perusahaan-perusahaan dan telah mengajukan izin kepada lembaga Otoritas Jasa Keuangan untuk terlibat dalam kegiatan perdagangan efek.

Dari penjelasan sebagaimana yang telah disebutkan sebelumnya, maka dapat dinyatakan bahwa Bursa Efek memiliki tiga karakteristik unik yang membedakan Bursa Efek sebagai perseroan dengan perusahaan perseroan pada umumnya. Apabila diperhatikan asal usul kata "perseroan", berasal dari kata "sero" yang artinya saham atau andil, sehingga perusahaan yang mengeluarkan saham atau sero disebut perseroan, sedangkan yang memiliki sero dinamakan "pesero" atau lebih dikenal dengan sebutan pemegang saham
(Sulaksono, 2011). Kemudian timbul pertanyaan, bagaimana halnya dengan perusahaan yang tidak mengeluarkan sero (saham)? Ternyata perusahaan tersebut juga disebut perseroan. Barangkali, yang paling sesuai untuk pemakaian kata "perseroan" adalah dalam hal penyebutan Perseroan Terbatas (PT), karena pada kenyataannya PT itu memang mengeluarkan saham atau sero. Seluruh modal PT terbagi dalam saham, sebagaimana dinyatakan dalam Pasal 1 ayat (1) Undang-Undang Nomor 40 Tahun 2007 tentang Perseroan Terbatas (Kurniawan, 2014).

Dari pernyataan yang telah disebutkan demikian, Bursa Efek yang merupakan badan hukum berbentuk perseroan merupakan salah satu contoh perseroan yang tidak mengeluarkan saham dikarenakan di dalam bursa efek itu sendiri memiliki sistem kerja tersendiri yang bersifat kerjasama antar anggota bursa sehingga anggota bursa yang merupakan para pesero bagi bursa efek memiliki hak dan kewajiban yang sama dalam hal kepemilikan atas Bursa Efek itu sendiri. Bursa efek merupakan asosiasi atau perkumpulan yang bersifat mutual yaitu kepemilikan sahamnya dipegang oleh para anggotanya (mutual associations owned by their members). Hal ini yang disebut sebagai "mutualisasi bursa" yaitu perantara pedagang efek berposisi sebagai anggota dan juga sekaligus sebagai pemilik atau pemegang saham di Bursa Efek. Umumnya Bursa Efek yang bersifat mutual menjalankan kegiatan dengan tidak berorientasi pada keuntungan semata dikarenakan keuntungan yang diperoleh Bursa Efek akan dikembalikan lagi kepada setiap anggota bursa dengan cara biaya transaksi perdagangan efek maupun biaya akses diberikan semurah mungkin (Rahmah, 2019).

Perusahaan merupakan suatu bentuk usaha yang melakukan kegiatan secara tetap dan berkelanjutan dengan tujuan memperoleh keuntungan atau laba, baik yang diselenggarakan oleh orang perorangan maupun badan usaha yang berbentuk badan hukum atau yang bukan berbentuk badan 
hukum. Perusahaan juga dapat diartikan sebagai badan yang menjalankan usaha, baik kegiatan usaha yang dilakukan oleh perseorangan maupun kegiatan usaha yang dilakukan oleh badan usaha. Dari pernyataan tersebut, perusahaan yang menjadi anggota Bursa Efek menjalankan usahanya yakni dengan menjual efek perusahaan tersebut. Apabila suatu perusahaan efek tidak lagi menjadi anggota bursa karena tidak memenuhi persyaratan, maka secara otomatis perseroan tersebut tidak lagi memiliki hak menjadi pemegang saham Bursa Efek dan dalam jangka waktu 12 (dua belas) bulan wajib menjual sahamnya kepada perusahaan efek lain yang masih memenuhi syarat sebagai anggota bursa (Anwar, 2019).

Penjelasan Pasal 9 ayat (1) UndangUndang Pasar Modal menyatakan sebagai berikut :

"Bursa Efek merupakan lembaga yang diberi kewenangan untuk mengatur pelaksanaan kegiatannya. Oleh karena itu, ketentuan yang dikeluarkan oleh Bursa Efek mempunyai kekuatan mengikat yang wajib ditaati oleh anggota Bursa Efek, emiten yang efeknya tercatat di Bursa Efek tersebut, lembaga kliring dan penjaminan, lembaga penyimpanan dan penyelesaian, kustodian atau pihak lain yang mempunyai hubungan kerja secara kontraktual dengan Bursa Efek. Kendati demikian, dalam hal pembuatan peraturan mengenai kliring dan penyelesaian transaksi bursa, peraturan tersebut perlu dibuat bersama-sama dengan lembaga kliring dan penjaminan. Yang dimaksud dengan hal-hal lain dalam ayat ini adalah kewenangan Bursa Efek untuk menetapkan aturan tentang pemeriksaan terhadap anggota Bursa Efek, aturan yang berkaitan dengan mekanisme koordinasi pelaksanaan fungsi Bursa Efek dengan lembaga kliring dan penjaminan serta lembaga penyimpanan dan penyelesaian, dan untuk mengantisipasi perkembangan di masa yang akan datang. Kesepadanan efek adalah sifat dari efek yang dapat dipertukarkan dengan efek sejenis yang mempunyai nilai yang sama dan diterbitkan oleh emiten yang sama."
Dari pernyataan tersebut, maka dapat dipahami bahwa Bursa Efek sebagai perseroan merupakan suatu lembaga yang diamanatkan oleh ketentuan peraturan perundang-undangan yang terkait, yakni Undang-Undang Nomor 8 Tahun 1995 tentang Pasar Modal yang diberi kewenangan untuk mengatur pelaksanaan kegiatannya, yakni kegiatan perdagangan efek di pasar modal serta bertindak juga sebagai pengawas bagi para anggota bursa yang menanamkan sahamnya di Bursa Efek itu sendiri.

Sebagaimana yang telah dijelaskan sebelumnya, bahwa Bursa Efek merupakan salah satu bentuk perseroan yang memiliki karakteristik yang berbeda dengan bentukbentuk perseroan pada umumnya. Bursa Efek merupakan pasar keuangan untuk danadana jangka panjang dan merupakan pasar yang konkret. Dana jangka panjang maksudnya adalah dana yang jatuh temponya lebih dari satu tahun. Adapun pasar yang konkret artinya pasar itu dilaksanakan secara terbuka dan nyata, dengan mekanisme yang transparan. Bursa Efek juga merupakan suatu sistem yang terorganisir yang mempertemukan penjual dan pembeli efek yang dilakukan baik secara langsung maupun tidak langsung. Efek yang dimaksudkan disini adalah semua surat berharga (sekuritas) yang diterbitkan oleh perusahaan misalnya: saham, obligasi, tanda bukti utang, bukti right (Right Issue), dan waran (Warrant). Sehingga dari pernyataan tersebut, dapat dinyatakan bahwa Bursa Efek merupakan perseroan yang menjadi sarana bagi emiten dan/atau para pihak yang terlibat dalam kegiatan perdagangan efek di pasar modal dengan para investor yang hendak mengadakan jual beli surat-surat berharga baik itu melalui penawaran perdana ataupun melalui pasar sekunder (Muklis, 2016). Bursa Efek sangat tidak menampakkan ciri-ciri perseroan yang umum, hanya saja bursa efek ditetapkan sebagai perseroan dengan dasar pengaturan yang terdapat pada Undang-Undang Nomor 8 Tahun 1995 Tentang Pasar Modal. 
Bursa Efek dalam hal ini adalah Bursa Efek Indonesia yang berkantor pusat di Jakarta dan memiliki beberapa perwakilan yang terdapat di berbagai daerah, salah satunya ada di Surabaya dimana dahulu pernah berdiri Bursa Efek Surabaya yang khusus menangani transaksi surat berharga obligasi, juga memiliki struktur kepengurusan yang dapat dikatakan sama seperti halnya struktur kepengurusan dalam perseroan pada umumnya. Struktur kepengurusan dalam Bursa Efek Indonesia terdiri atas para kepala divisi, jajaran direksi, sekretaris perusahaan, inspektorat, dan Direktur Utama sebagai kepala pimpinan dan bentuk pertanggungjawaban struktur kepengurusan tersebut diawasi oleh jajaran komisaris. Hal ini mengisyaratkan bahwa Bursa Efek Indonesia tunduk pada UndangUndang Nomor 8 Tahun 1995 tentang Pasar Modal dan Undang-Undang Nomor 40 Tahun 2007 tentang Perseroan Terbatas. Dikarenakan Bursa Efek Indonesia merupakan perseroan yang dibentuk berdasarkan amanat dari Pasal 6 UndangUndang Nomor 8 Tahun 1995 tentang Pasar Modal, maka Bursa Efek Indonesia merupakan salah satu bentuk perseroan yang dibentuk oleh negara.

Persero sebagai akronim dari Perusahaan Perseroan, merupakan salah satu bentuk badan usaha negara, tetapi ditundukkan kepada ketentuan-ketentuan hukum yang berlaku untuk Perseroan Terbatas. Pada masa berlakunya KUHD (Kitab Undang-Undang Hukum Dagang) diberlakukan ketentuan-ketentuan Pasal 36 sampai dengan Pasal 56 KUHD. Kemudian diberlakukan ketentuan Undang-Undang Nomor 1 Tahun 1995 tentang Perseroan Terbatas, pada waktu berlakunya undangundang ini. Kemudian dengan berlakunya Undang-Undang Nomor 40 Tahun 2007 tentang Perseroan Terbatas, diberlakukan ketentuan-ketentuan yang ada dalam peraturan tersebut. Untuk pertama kali kita mengenal bentuk ini sejak terbitnya Instruksi Presiden Nomor 17 Tahun 1967 tentang Penanaman Modal Asing dan
Undang-Undang Nomor 9 Tahun 1969 tentang Penanaman Modal Dalam Negeri.

Namun, Bursa Efek Indonesia bukan merupakan Badan Usaha Milik Negara dikarenakan pihak yang memegang saham atas bursa efek itu sendiri adalah para anggota bursa itu sendiri. Menurut Pasal 1 UU No. 19 Tahun 2003 tentang BUMN (Badan Usaha Milik Negara), BUMN adalah badan usaha yang seluruh atau sebagian besar modalnya dimiliki oleh negara melalui penyertaan secara langsung yang berasal dari kekayaan negara yang dipisahkan. Dari pernyataan mengenai definisi BUMN di atas dapat ditarik kesimpulan, bahwa ada beberapa unsur yang membuat suatu perseroan dapat dikategorikan sebagai BUMN yakni merupakan badan usaha, modal yang seluruh atau sebagian besar dimiliki oleh negara, negara melakukan penyertaan modal secara langsung dan bersumber dari kekayaan negara yang dipisahkan (Khairandy, 2013).

\section{Status Yuridis Bursa Efek}

Permasalahan berikut adalah apa dan bagaimana status hukum yang tepat bagi Bursa Efek itu sendiri. Bentuk hukum perseroan terbatas (PT) dianggap bukan bentuk organisasi yang tepat bagi Bursa Efek Indonesia (BEI). Pernyataan tersebut disampaikan oleh Sarmauli Yuris Christi Simangunsong saat mengikuti ujian terbuka program doktor di Fakultas Hukum UGM. Partner pada Nindyo \& Associates ini menerangkan, bahwa PT. BEI merupakan kumpulan para anggota bursa yang masingmasing anggota bursa memiliki 1 lembar saham PT. BEI. Kepemilikan 1 lembar saham ini menandakan bahwa kepemilikan saham PT. BEI lebih sebagai bentuk tanda keanggotaan dibandingkan sebagai kepemilikan saham selayaknya dalam perseroan terbatas pada umumnya. Selain itu, terdapat pula larangan pembagian dividen bagi para pemegang sahamnya sehingga pengertian perseroan terbatas sebagai kumpulan modal tidak tepat diterapkan kepada PT. BEI (Gloria, n.d.). 
Di dalam kajian hukum lelang pun, PT. BEI memiliki ketentuan tersendiri yang mengatur mengenai mekanisme lelang saham sehingga tampak bahwa PT. BEI perlu ditetapkan status badan hukumnya dengan jelas. Pengaturan penjualan lelang saham diatur di dalam PP No. 12 Tahun 2004 tentang Penyelenggaraan Kegiatan di Bidang Pasar Modal. PT. BEI adalah badan hukum yang berbentuk perseroan yang memperoleh izin dari Otoritas Jasa Keuangan untuk melaksanakan kegiatan bursa saham. Melihat pengalihan hak atas saham PT. BEI disebut dalam Peraturan Pemerintah, maka dalam ketentuan lelang tersebut masuk ke dalam jenis lelang non eksekusi wajib. Hal itu dikarenakan diwajibkan oleh Peraturan Pemerintah tetapi objek yang dilelang bukan jaminan yang dieksekusi (Tista, 2013). Maka seharusnya berdasarkan PP No. 3 tahun 2018 tentang Jenis dan Tarif Atas Jenis Penerimaan Negara Bukan Pajak yang berlaku pada Kementerian Keuangan, maka atas lelang non eksekusi wajib akan dikenakan Bea Pembeli sebesar 2\% dari harga lelang terbentuk dan lelang wajib melalui KPKNL (Kantor Pengelola Kekayaan Negara dan Lelang) dan dilakukan di hadapan Pejabat Lelang Kelas I.

Pada penjelasan yang telah dipaparkan sebelumnya bahwa selain Bursa Efek tidak tepat disebut sebagai perseroan terbatas, Bursa Efek juga tidak tepat disebut sebagai badan hukum layaknya persekutuan atau perkumpulan. Pada dasarnya perusahaan persekutuan adalah perusahaan yang dimiliki oleh dua orang atau lebih yang disebut sekutu. Sehingga, dalam bentuk usaha tersebut terdapat aturan hukum yang mengatur hubungan hukum diantara para sekutu yang dikenal dengan aspek hukum internal dan aturan yang mengatur hubungan hukum antara para sekutu dengan pihak ketiga yang dikenal dengan aspek hukum eksternal (Putri, 2020).

Bursa Efek juga tidak tepat disebut sebagai organisasi nirlaba seperti yayasan dikarenakan yayasan sebagai badan hukum memiliki karakter yang khas. Jenis badan hukum ini lahir karena adanya suatu perbuatan hukum yakni pemisahan sejumlah kekayaan dari para pendiri dengan tujuan tertentu yang umumnya bukan untuk meraih keuntungan (Simamora, 2012). Bursa Efek pada hakikatnya adalah suatu pasar, seperti juga pasar yang bersifat konvensional yang mempertemukan penjual dan pembeli. Berkaitan dengan itu dapat dikemukakan bahwa kegiatan Bursa Efek pada dasarnya adalah menyelenggarakan dan menyediakan sistem dan/atau sarana perdagangan efek bagi para anggotanya (Nasution, 2015).

\section{Simpulan}

Kesimpulan yang dapat ditarik dari penulisan ini adalah Bursa Efek Indonesia sebagai lembaga yang dibentuk dan diatur amanatnya dalam Undang-Undang Nomor 8 Tahun 1995 tentang Pasar Modal merupakan salah satu subjek hukum berbentuk perseroan berbadan hukum yang diberi kewenangan oleh Undang-Undang tersebut untuk menyelenggarakan kegiatan perdagangan efek dalam pasar modal dan mengatur kinerja para anggota bursa yang merupakan perusahaan-perusahaan perseroan yang telah memiliki izin dari lembaga Otoritas Jasa Keuangan untuk dapat terlibat langsung dalam kegiatan perdagangan efek.

Status Yuridis Bursa Efek itu sendiri merupakan perseroan yang memiliki aturan kerja tersendiri sehingga memiliki perbedaan dibanding perseroan pada umumnya dikarenakan Bursa Efek sebagai perseroan yang bersifat nirlaba dalam arti tidak mencari dan membagikan keuntungan untuk kepentingan komersial, tetapi lebih ditujukan untuk kepentingan kegiatan perdagangan efek yang dilaksanakan di Bursa Efek secara khusus dan pasar modal secara umum.

Penulis menyampaikan suatu gagasan berdasarkan analisa yang telah dijelaskan dalam penulisan ini bahwa Bursa Efek perlu diatur dalam Undang-Undang tersendiri dikarenakan Bursa Efek sebagai perseroan memiliki aturan main yang berbeda dibandingkan dengan aturan main perseroan 
pada umumnya dengan pertimbangan hukumnya adalah jika diatur dalam UndangUndang tersendiri, maka jelas kedudukan status hukum dan aturan main Bursa Efek itu sendiri sebagaimana di dalam peraturan perundang-undangan yang mengatur mengenai peradilan seperti Undang-Undang tentang Kekuasaan Kehakiman. Selain itu juga, apabila diatur dalam Undang-Undang tersendiri, Bursa Efek akan lebih dikenal publisitasnya kepada khalayak umum.

\section{DAFTAR PUSTAKA}

Anwar, B. A. (2019). Karakteristik Bursa Efek Sebagai Self Regulatory Organization. Justitia Jurnal Hukum, 3(1), 39-49.

Gloria. (n.d.). Bentuk Hukum Perseroan Terbatas Tidak Tepat bagi BEI. Retrieved January 30, 2019, from https://www.ugm.ac.id

Khairandy, R. (2013). Karakter Hukum Perusahaan Perseroan Dan Status Hukum Kekayaan Yang Dimilikinya. Jurnal Hukum IUS QUIA IUSTUM, 21(1), 81-97.

Kurniawan. (2014). Tanggung Jawab Pemegang Saham Perseroan Terbatas Menurut Hukum Positif. Mimbar Hukum, 26(1), 72-86.

Muklis, F. (2016). Perkembangan Dan Tantangan Pasar Modal Indonesia. Al Masraf (Jurnal Lembaga Keuangan
Dan Perbankan), 1(1), 65-76.

Nasution, Y. S. J. (2015). Peranan Pasar Modal Dalam Perekonomian Negara. Human Falah, 2(1), 96.

Paulina, N. S.; D. H. P. (2018). Karakteristik Badan Hukum Rumah Sakit Swasta Di Indonesia. Jurnal Alethea, 1(2), 185-200.

Permatasari, R. (2018). Akibat Hukum Perseroan Terbatas Yang Didirikan Oleh Suami Istri Tanpa Perjanjian Kawin. Mimbar Keadilan, 14(28), 225236.

Putri, A. A. (2020). Analisis Konflik Hukum Dan Simulasi Pernyataan Pendirian Perseroan Terbatas Oleh Pendiri Tunggal. Indonesian Notary, 2(4), 854 878.

Rahmah, M. (2019). Hukum Pasar Modalj. Kencana.

Simamora, Y. S. (2012). Karakteristik, Pengelolaan Dan Pemeriksaan Badan Hukum Yayasan Di Indonesia. Jurnal Rechtsvinding, 1(2), 1.

Sulaksono, A. (2011). Perlindungan Pemodal Reksadana Melalui Good Corporate Government (Studi Kasus Bank Global). Perspektif, 16(3), 173183.

Tista, A. (2013). Perkembangan Sistem Lelang Di Indonesia. Al-Adl: Jurnal Hukum, 5(10), 46-70. 